\title{
Discussion of the Classroom Design of Professional Courses Used in Army Academy
}

\author{
Dongli Liu \& Hui Yang \& Xiaofang Shao \\ Dalian Naval Academy, Dalian, China, 116018
}

\begin{abstract}
With the army person with ability strategic project is accelerating, professional education will be the main body of military academies education. The quality of professional education consists in the quality of classroom teaching. In this paper, the radar range qua example to discuss classroom design. Analysis the teaching characteristic and teaching target, Investigate thorough the important tache of classroom design. Aimed at inaugurate teaching design and definitude the significance of classroom teaching and offer reference for the innovation of information teaching method.
\end{abstract}

KEYWORD: professional education; classroom design; teaching method; innovation thinking

\section{INTRODUCTION}

\subsection{The necessity of class design}

Military academy education refers to the officer's vocational education, on the basis of the complete record of formal schooling education, in order to meet the need of job promotion. Compared with the previous record of formal schooling education, post education with post pertinence, timelines, skill, practical knowledge, comprehensive quality, diversity training, etc.

In order to develop students' ability of suiting their position, to improve students' professional skills, colleges and universities plays a key role in students education, having a direct impact on students' personal development and construction of naval career. Education is like a lighthouse on the sea for students getting the first direction.

We must pay special attention to classroom which thought as a key battleground for education. This requires that we teachers recognize the importance of classroom design, designing carefully for each lesson in the course of classroom work.

\subsection{The significance of class design}

Richards has proposed that whether a class can achieve a satisfactory teaching effect, usually depends on effectiveness at the beginning of designing[1], this requires that each faculty do their homework in the classroom design, understanding the classroom design contains deep connotation of the content, designing elements, etc. So-called classroom design and the specific teaching goal is to achieve a cycle and the arrangement of a series of teaching activities, including the implementation of each teaching link as well as records of these activities Teachers set each role carefully and perform the task previously, and preparing a lesson just an initial part of the whole process of classroom design [2].

At present, the question is: before the classroom design, applied to the design of curriculum, what should be specific grasped, what problem should be came up with to achieve a high-quality class?

Based on years of teaching experience, in view of the classroom design problem, this paper tries to use course" shipboard radar and operational use" and the course design of "radar range" as example, explore the basic elements of classroom design, clear the basic requirement of the class design, providing the reference to promote the reform of classroom teaching, classroom innovation design ideas.

\section{THE BASIC ELEMENTS OF CLASSROOM DESIGN}

In order to do a good job in the classroom design, we should fully consider many elements, starting from the teaching task, based on the actual situation of the teaching object, understanding the status and characteristics of curriculum ideas and teaching, to develop the teaching goal, teaching forms, optimize the teaching process, do a good job of teaching evaluation and feedback. One of the most important 
and the most difficult is mastering teaching status, characteristic, objective requirement. Teachers in their class design should emphatically grasp these two elements, and those are the basis of subsequent class teaching ideas, teaching resources control, etc.

\subsection{Understand the status and characteristics of teaching content}

Class design must first start from the whole picture, make the curriculum ideas clear, identify the position and role of the teaching content in the curriculum system, master the teaching content and characteristics.

(1) Curriculum ideas

In order to better clarify curriculum ideas, we should both further analyze the teaching arrangement, and having a overview of the course position in the whole process of education.

Ship borne radar and operation use is suitable for the surface ship command post education of lightning and is one of the major and comprehensive subjects. The course is divided into three modules, including the principle of radar, radar equipment, and operation, every module is connected with each other, from the easy to the difficult, and step by step. The first module is the principle of radar, and it is the basis of the other two modules, and it is also the theoretical knowledge of studying and analyzing equipment store.

(2)The position of this section

The position and function of individual sections of knowledge should be from the overall curriculum perspective, analysis of the knowledge context. "Radar range" of this class is the last section of the first module of the radar principle, and it is the comprehensive use of the previous section (transmitter, antenna, feeder, receiver and monitor). Radar range is the most important parameter of radar and it is very important for the follow-up study of radar equipment. Therefore, this course is a section of connecting, so it must be thoroughly explained the difficult and important points.

(3)The features of this section

Each section has its own characteristics, so it should catch the more important points in the process of classroom design and promote the advantages and avoid disadvantages. This section has both theoretical derivation and the actual application; it concludes the exploration of knowledge points in depth and the transverse comprehensive knowledge points; it not only includes all kinds of of knowledge in class, but also paves the way for the following contents. Therefore, it needs deepening the important contents and analysising difficult contents and solving the problems of practical military equipment and post combination. So in order to deepen the understanding on the basis of the actual application, it should also overcome the theoretical derivation of boring as much as possible.

\subsection{Make teaching objectives and requirements clear}

The teaching goal is the starting point of teaching, and it is also the ending point. It has a certain guiding affect to the whole teaching processes. About this section, the teacher should pay attention to the details, base on the teaching contents, know the important and difficult points, and make the teaching objectives clear. In the establishing the teaching goals, it should start from the post needs and give full consideration to the actual needs of teaching goals.

(1) Teaching contents

This section includes the following teaching contents:

Knowledge point 1: radar equation

Knowledge point 2: The parameters affecting the radar equation of radar range (the important point)

Knowledge point 3: The relationship between the radar line of sight and the radar range

Knowledge point 4: Atmospheric effects on radar range (the difficult point)

(2) Teaching objectives

The teaching objectives not only pay attention to the theoretical knowledge, but also focus on the development of ability. Meanwhile, to meet the requirements of different levels of learners, the teaching objectives should make sure the objectives according to the learning marerials.

1) Theoretical knowledge learning: Master the knowledge of basic radar equation and the actual factors' affect on the radar range; encourage the learners to analyze and compare the principle of radar and electronic warfare

2) Development of ability

The ability of comprehensive knowledge and migrate knowledge; the ability of individual consideration; the innovation ability of the connecting theory and application; the quality of post needed; the talents which have the quality of the combination of command and skill.

\section{CLASSROOM CURRICULUM DESIGN REQUIREMENTS}

Class excellent design is based on the following points:

\subsection{Make the design of outline clear}

The classroom design is based on the teaching contents, combined with the characteristics of learners themselves, is followed by class design 
evaluation, and grasps the main theme in class, the leading point and the breakthrough.

Aiming at the evaluation of the excellent lesson about military colledge, it focuses on classroom teaching design. According to the lesson of radar horizon, the teaching design is like the following table 1:

According to the characteristics of learners of military college, on the basis of the features and teaching objectives of this section, the design outline is: the major point is the derivation of the radar equation, discussion of the influence of various parameters on radar range, Integration of knowledge points, the section solves the problem of theory connecting to practice and closing to the first working in the post.

\subsection{Organize and arrange teaching}

\subsubsection{Organized principles}

(1) Pay attention to the key points

About key points, the teacher should make them stand out. For example: analyze and understand them by using more time; explain them by real examples; give the right homework and questions; focus on the blackboard design and review the notes.

Table 1 the relation between teaching design and evaluation point

\begin{tabular}{|c|c|c|c|}
\hline The first target & The second target & The teaching design & remarks \\
\hline \multirow{2}{*}{$\begin{array}{l}\text { Teaching } \\
\text { objectives }\end{array}$} & Adaptive & Suitable for the requirement of the lessons & \multirow{2}{*}{$\begin{array}{l}\text { Closely related to the curriculum } \\
\text { standard }\end{array}$} \\
\hline & prospective & Close to the post, to supplement the relevant knowledge & \\
\hline \multirow{3}{*}{$\begin{array}{l}\text { Teaching } \\
\text { contents }\end{array}$} & basic & $\begin{array}{l}\text { Explain knowledge } 2 \text { and give examples, emphasize the } \\
\text { meaning of every parameters, and adjust the arrangement of } \\
\text { contents }\end{array}$ & \multirow{3}{*}{$\begin{array}{l}\text { Strengthen the force of real } \\
\text { equipments; Increase the amount } \\
\text { of information, and the } \\
\text { prominent military features. }\end{array}$} \\
\hline & academic & Add the frontiers of knowledge of the atmospheric duct. & \\
\hline & thought & $\begin{array}{l}\text { Connecting with the application, explain knowledge } 2 \text { and } 3 \text {, } \\
\text { discuss the implications for operational use. }\end{array}$ & \\
\hline \multirow{3}{*}{$\begin{array}{l}\text { Teaching } \\
\text { procedures }\end{array}$} & inspirational & & \multirow{3}{*}{$\begin{array}{l}\text { Guide the learners to think in the } \\
\text { process of derivation, and leave } \\
\text { the space of imagination. }\end{array}$} \\
\hline & art & $\begin{array}{l}\text { last } 4 \text { sections, encourage thinking, arrange the Discussion of } \\
\text { the role of work wave length influence on the distance and } \\
\text { give a question }\end{array}$ & \\
\hline & technical & $\begin{array}{l}\text { Combine high quality multimedia and animation. use the } \\
\text { network course teaching resources. }\end{array}$ & \\
\hline $\begin{array}{l}\text { Teaching } \\
\text { effects }\end{array}$ & information & $\begin{array}{l}\text { Add the actual pictures of equipments; Calculation examples } \\
\text { by using radar equation; the atmospheric environment's } \\
\text { affect on the distance by Combining with the operational } \\
\text { background. }\end{array}$ & $\begin{array}{l}\text { Stimulate learners' learning } \\
\text { interests. }\end{array}$ \\
\hline
\end{tabular}

\subsubsection{Application arrangement}

According to the above organized principles, the application arrangement of this section is like that:

(1) The arrangement of teaching contents and time:

Knowledge Point 1
Knowledge Point 2
Knowledge Point 3
Knowledge Point 4
Summary

15 minutes;

30 minutes;

10 minutes;

10 minutes;

5 minutes;

Knowledge Point 2 needs to talk about the depth of the knowledge and put it into practice. Knowledge point 4 needs to have a breadth of knowledge points and explain the environmental impact on radar distance clearly.

(2) The main design of teaching content

According to the overall design concept based on this class, it will be apparent to see that the main teaching is very clear, that is the derivation, discussions and applications of radar range. It divided into four stages, and they are the lead period, bedding segment, climax and extended segment.
(3) The convergence of teaching content design

Dealing with transforms and natural transition for each knowledge point well is to prompt the combination of teaching stage and highlight the clear teaching ideas so that students can understand and absorb it easily.

(4) Connection and echoing of teaching content

Introduction and explanation of new knowledge should be efficient to reference the old knowledge as well as develop new content.

(5) The implementation process of teaching content design. Point to the figure one.

\subsection{Enrich the teaching methods}

\subsubsection{Teaching methods varied}

According to the characteristics of this teaching content, we mainly use formula-based and heuristic methods supplemented to explain knowledge point 1; about knowledge point 2, we use heuristic method, question-and-answer methods and discussion method. Through different discussions, 
they can lead to the conclusion in order to achieve the "finishing touch" role. Therefore they can to stimulate the students' enthusiasm for learning and foster their spirit of innovation; knowledge point 3, is explained by way of example. Students make their own examples by calculating with the actual results inconsistently. They can understand the concept of the radar horizon which reflects the main role of the students; knowledge point 4, succinct method is adopted. Simplify and refine the complex course content in order to improve the effectiveness of teaching.

\subsubsection{Enrich teaching methods}

The education of radar equation is given by using video. It leads to the importance of the radar equation by watching a movie for one and a half minutes; the discussion for radar equation of each parameter, we use teaching resources online, mainly including radar images, interface and so on to deepen students' understanding of abstract knowledge; for atmospheric effects on radar range, we use the multimedia made by ourselves to simulate electromagnetic wave to get the attenuation curves. They are given in the form of conclusions. This played a concise and clear summarized role.

\subsection{Promote students to become talented people}

Teacher's responsibility is not just "imparting the knowledge and explaining the puzzle," but "preaching." In class, the teacher should make use of the opportunity appropriately to conduct a comprehensive education to increase the highlights of teaching.

\subsubsection{Innovative education thinking design}

According to teaching content and features based on the course, when we are explaining the knowledge, after having discussed all parameters' effect on radar distance and giving the question "in terms of improving radar range, how to play the human factor", we should consider practical situation of the forces to encourage students to think actively, find and solve problems. Try to develop their sense of innovation, and guide their correct world outlook and values to achieve the purpose of educating people.

\subsubsection{The design of doing things in a philosophical way}

The philosophical thinking integrated helps to improve the teaching level, but not all of the teaching contents have such an opportunity. This course explains the knowledge when we explain point 2, we discuss how to improve the radar range and discuss the various parameters in detail, such as radar transmits power. Other problems brought by improving the radar transmitter power and it will increase the cost and increase the volume of equipment as well as lead to reliable decreased. After finishing this, you can use the "contradictions are everywhere in the theory of radar equipment, we must consider the impact syndrome local parameters on the overall performance critically" to summed up so that students can have a dialectical view of things, get into the habit of analyzing and complete in philosophy Teaching penetration.

\section{CONCLUSION}

Talent is the driver of social development; education is the cornerstone of personnel training; class is the main battlefield of education. Therefore, a teacher who is the "general director" of a class takes the sacred responsibility of training talented people. With the deep development of curriculum reform, the scope of the new curriculum has been transited from teaching content to the form of class teaching methods. New Era begins, under the guidance of new teaching ideas, we should do our own work, further optimize the class design according to the requirements of the new program and make a good design for each class. Thus we can promote the reform of teaching, accelerate the pace of cultivating military information talents and improve the quality of education.

\section{REFERENCES}

[1] Richards, J. C. What's the use of lesson plans? In J. C Richards (Ed), Beyond Training. New York: Cambridge University Press, 1998(103-121).

[2] Liang Ting Classroom design theory and its enlightenment to college English classroom teaching. Higher education research 11, 2011.

[3] XinGong colour Chen Weilun Qian Kun etc. To optimize the classroom teaching, improve teaching effect. Education in time and space 3,10 .

[4] Li Gong Perfect the system of the college classroom teaching method of the new exploration The theory of vertical and horizontal 2010.10(11):109-111.

[5] Jiang Shu Lian Perfect design, the implementation of quality education. Education front. 2010.09:133-134.

[6] LI Xiu Lian Wang Zhi Yong Theory of classroom teaching quality and teaching elements in relationship. Journal of liaoning normal university (social science edition) 2010. 33(6):57-59. 